\title{
Abiotic Stress Effects on Plants under Climate Change
}

\author{
Subodh Kr. Bishnoi ${ }^{{ }^{*}}$, R. P. S. Chauhan ${ }^{1}$, Naresh Kr. Yadav ${ }^{1}$ and Pooja Bishnoi ${ }^{2}$ \\ ${ }^{1}$ Agricultural Research Station, SK Rajasthan Agricultural University, Bikaner, Sriganganagar, Rajasthan (335 001 ), India \\ ${ }^{2}$ Govt. National College, Sirsa, Haryana (125 055), India
}

Corresponding Author

Subodh Kr. Bishnoi

e-mail: bishnoisk@gmail.com

\author{
Article History \\ Article ID: AR1814d \\ Received in 20 2 th May, 2017 \\ Received in revised form $25^{\text {th }}$ October, 2017 \\ Accepted in final form $19^{\text {th }}$ November, 2017
}

\begin{abstract}
Abiotic stress is a stress that occurs as a result of damage done to plants by non-living and often tangible factors such as intense sunlight, wind etc. This naturally occurring stress is most detrimental to plant health when it influences the environment beyond its normal range of variation. Since abiotic stresses originate from surrounding environment therefore, these are more harmful for plants than animals as plants are dependent on environmental factors. Research has also shown that abiotic stressors are at their most harmful when they occur together, in combinations of abiotic stress factors. Extended exposure to extreme temperatures, high salinity, etc results in certain physiological and biochemical changes in plants that adversely affect the growth and productivity of crops worldwide. Plant biodiversity is determined by many things, and one of them is abiotic stress. If an environment is highly stressful, biodiversity tends to be low. If abiotic stress does not have a strong presence in an area, the biodiversity will be much higher. This means that species are more likely to become plants population threatened, endangered, and even extinct, when and where abiotic stress is especially harsh. Thus, abiotic stress leads to altered metabolism and damage to bio-molecules and is responsible for reduced yield in several major crops. In this review, we summarize recent progress on systematic analysis of plant responses to abiotic stress. Abiotic stresses are serious threats to agriculture and the environment which have been exacerbated in the current century by global warming and industrialization.
\end{abstract}

Keywords: Stress, abiotic stress, drought, temperature stress

\section{Introduction}

Abiotic stresses are serious threats to agriculture and the environment which have been exacerbated in the current century by global warming and industrialization. Today, in a world of 7 billion people, agriculture is facing great challenges to ensure a sufficient food supply while maintaining high productivity and quality standards. In addition to an ever increasing demographic demand, alterations in weather patterns due to changes in climate are impacting crop productivity globally. Unfavorable climate (resulting in abiotic stresses) not only causes changes in agro-ecological conditions, but indirectly affects growth and distribution of incomes, and thus increasing the demand for agricultural production (Fukuda, 2000).

Abiotic stress is defined as the negative impact of non-living factors on the living organisms in a specific environment (Pennell and Lamb, 1997). Abiotic stresses include drought, excess water, salinity, heat, cold, wounding, exposure to xenobiotics (now including chemical pollution) and UV radiation. Furthermore plants are also confronted by biotic stresses through microbial pathogens such as fungi, nematodes and bacteria (Tippmann et al., 2006). Some of the most serious effects of abiotic stresses occur in the arid and semiarid regions where rainfall, high evaporation low, native rocks, saline irrigation water, and poor water management all contribute in agricultural areas (Vahdati and Leslie, 2013). Stress research has traditionally focussed on single stress aspects. However, in their natural environment, plants have to adapt to numerous environmental stresses at the same time and different stresses can occur at different stages of the plant's life cycle. The adaptation to various stresses has led to the development of common stress transduction pathways and includes, among others, the increased synthesis of secondary metabolites, $\mathrm{Ca}^{2+}$ fluxes, an oxidative burst and an overlapping set of stress response genes (Cheong et al., 2002; Roberts et al., 2002). Abiotic stress leads to a series of morphological, physiological, biochemical and molecular changes in plants that adversely affect growth and productivity. Stresses also affect the biosynthesis, concentration, transport, and storage of primary and secondary metabolites. As a more comprehensive view of these processes evolves, applications to reducing plant stress are emerging (Vahdati and Leslie, 2013). 
Abiotic stress comes in many forms. The most common of the stressors are the easiest for people to identify, but there are many other, less recognizable abiotic stress factors which affect environments constantly. The most basic stressors include: high winds, extreme temperatures, drought, flood, and other natural disasters, such as tornadoes and wildfires. The lesser-known stressors generally occur on a smaller scale and so are less noticeable, but they include: poor edaphic conditions like rock content and $\mathrm{pH}$, high radiation, compaction, contamination, and other, highly specific conditions like rapid rehydration during seed germination (Jump et al., 2006).

\section{Features of Salinity, Cold and Drought Stress}

Salinity, cold and drought stress are all osmotic stresses: they cause a primary loss of cell water, and, therefore, a decrease of cell osmotic potential. However, the elicitor of cell water loss differs between stresses: i) salinity stress decreases cell water content due to the decrease of external water potential, caused by the increased ion concentration (mainly $\mathrm{Na}^{+}$and $\mathrm{Cl}^{-}$), turning more difficult water uptake by roots and water translocation to metabolically active cells; ii) cold stress decreases cell water content due to the socalled physiological drought, i.e., the inability to transport the water available at the soil to the living cells, mainly the ones of the leaf mesophyll; iii) the decrease of the cell water content under drought stress is due to water shortage in soil or/and in the atmosphere. Anyway, dehydration triggers the biosynthesis of the phytohormone abscisic acid (ABA) and it has been known for a long time that a significant set of genes, induced by drought, salt, and cold stresses, are also activated by ABA (Boudsocq and Lauriere, 2004).

Different combinations of biotic and abiotic stresses are presented in the form of a matrix to demonstrate potential interactions that can have important implications for agriculture. Different interactions are color coded to indicate potential negative [i.e. enhanced damage or lethality owing to the stress combination (purple)] or potential positive [i.e. cross-protection owing to the stress combination (green)] effects of the stress combination on plant health. However, the potential effects of stress combination could vary depending on the relative level of each of the different stresses combined (e.g. acute versus low) and the type of plant or pathogen involved. Data to generate the matrix was obtained.

\section{Temperature}

Temperature stress is becoming the major concern for plant scientists worldwide due to the changing climate. The difficulty of climate change is further added considering its precisely projecting potential agricultural impacts (Watanabe and Kume, 2009; Shah et al., 2011). Temperature stress has devastating effects on plant growth and metabolism, as these processes have optimum temperature limits in every plant species. Global climate change is making high temperature
(HT) a critical factor for plant growth and productivity; HT is now considered to be one of the major abiotic stresses for restricting crop production (Hasanuzzaman and Hossain, 2012).

The most observed effect of heat stress on plants is the retardation of growth. As heat stress often occurs simultaneously with drought stress, the combination of drought and heat stress induce more detrimental effect on growth and productivity of crops than when each stress was applied individually (Prasad et al., 2008). In higher plants, heat stress significantly alters cell division and cell elongation rates which affect the leaf size and weight. However, it was reported that heat stress resulted in significant increases in leaf numbers, particularly when reproductive development was arrested without any decrease in leaf photosynthetic rates (Prasad et al., 2006; Prasad et al., 2008). Exposure of plants to severe heat stress decreased the stem growth resulting in decreased plant height (Prasad et el., 2006; Rahman, 2004; Ahamed et al., 2010) reported that plant height of wheat plant ranges from $66.4-97.3 \mathrm{~cm}$ and $55.7-82.3$ $\mathrm{cm}$ in normal and heat stress condition, respectively. While studying with $T$. aestivum, Ahamed et al., (2010). observed that sowing time mediated heat stress negatively influenced the plant height and number of tillers of 4 different genotypes. In a recent study, Al-Busaidi et al. (2012) observed that high atmospheric temperature causes significant water loss which negatively influenced the growth and biomass production in biofuel plant, Jatropha curcas. Parallel to shoot growth heat stress often decreases root growth, number of roots and root diameter (Porter and Gawith, 1999). Recently, Johkan et al. (2011) observed that the number of tillers in wheat plants decreased in response to $\mathrm{HT}$, especially high night-time temperatures, however shoot elongation was promoted. Prasad et al. (2011) reported that high night temperature $\left(31.9^{\circ} \mathrm{C} / 27.8^{\circ} \mathrm{C}\right.$ ) decreased chlorophyll (Chl) content and photosynthetic rate by $8 \%$ and $22 \%$, respectively, compared to optimum night temperature. In a recent study, Prasad et al. (2011) observed that spring wheat plants grown under HT $\left(31 / 18^{\circ} \mathrm{C}\right)$ showed a significant reduction in number of grains spike-1 (50\%), total dry weight (20\%), grain yield $(39 \%)$ and harvest index (24\%) as compared to optimum temperature $\left(24 / 14^{\circ} \mathrm{C}\right)$.

High temperature decreased shoot dry weight, relative growth rate (RGR) and net assimilation rate (NAR) in maize, millet and sugarcane (Wahid, 2007; Ashraf and Hafeez, 2004). In their review, Wahid (2007) mentioned that HT can cause considerable pre- and post-harvest damages, including scorching of leaves and twigs, sunburns on leaves, branches and stems, leaf senescence and abscission, shoot and root growth inhibition, fruit discoloration and damage. High temperature also alters the internal morphology (anatomy) of plants and these changes are generally similar to those under drought stress. Under HT stress, there is a general tendency towards reduced cell size, closure of stomata 
and curtailed water loss, increased stomatal density and trichomatous densities, and larger xylem vessels in both roots and shoots (Wahid, 2007). According to Angadi and Cutforth (2000), temperatures below $10^{\circ} \mathrm{C}$ result in slower and reduced growth and premature stem elongation in $B$. napus, B. rapa and Raphanus sativus. It is well reported that plants at their seedling stage are very much sensitive to cold stress. At early stage of plant growth, and various phenotypic symptoms in response to chilling stress are surface lesions, chlorosis, necrosis, desiccation, tissue break down and water soaked appearance of tissues, reduced leaf expansion, wilting (Solanke and Sharma, 2008; Jiang et al., 2002). Nahar et al. (2009) observed varieties of cold injury symptom is rice including stunted growth, yellowing of leaves, abnormal number of tiller, malformed grain, abnormal colors in grain.

\section{Programmed Cell Death as a Response to High Light}

\subsection{UV and Drought Stress in Plants}

FBecause of their sessile nature, plants are unable to avoid fluctuating environment conditions like high light, ultraviolet radiation, drought, salt stress, heat, cold or flooding. Upon certain threshold of these changes, plant cells can no longer maintain proper metabolic processes and programmed cell death (PCD) is induced.

There are two main categories of PCD in plants: developmentally-and environmentally-induced PCD. Example of developmentally- induced PCD is a formation of unisexual flowers in monoecious species (e.g. maize), bearing generative organs of both sexes on the same plant. Sex determination in these species involves the developmental arrest of one of the organ primordia-either the 2013 Wituszyńska and Karpiński; licensee InTech. This is an open access article distributed under the terms of the Creative Commons Attribution License (http://creativecommons.org/licenses/by/3.0), which permits unrestricted use, distribution, and reproduction in any medium, provided the original work is properly cited. Female or male within a bisexual floral meristem (Dellaporta and Calderane, 1993). The production of complex leaf shapes also frequently employs PCD. Such remodeling of leaf blades occurs in Monstera obliqua, Monstera deliciosa or lace plant (Gunawardena et al., 2004). These species tend to induce death pathway in some patches of cells and thus form distinctive perforations within the leaf (Gunawardena, 2008).

Moreover, PCD during senescence helps to block spreading of diseases to still vital parts of the plant (Gan and Amasino, 1995). Under heat stress leaf temperature and stomatal conductance increased significantly, whereas under drought and drought + heat stress condition photosynthesis and stomatal conductance decreased and leaf temperature increased as compare to control.

\section{High and Excess Light Stress}

Light is an essential factor in the regulation of plant growth, development and stress responses but it is also responsible for the production of reactive oxygen species leading to PCD. The cell death phenotype of many lesion mimic mutants of Arabidopsis thaliana and Zea mays is dependent on light (Jabs et al., 1996; Mach et al., 2001; Gray et al., 2002). Plant cells have been equipped with sophisticated light-perception mechanisms and signaling pathways that are very important for the plant defense. Three families of photoreceptors collecting different light qualities exist in plant cells: phytochromes (PHY), cryptochromes (CRY) and phototropins (PHOT).

In the last decade a significant progress has been made in improving light-induced oxidative stress tolerance in plants. Various components of anti-oxidative system involved in ROS scavenging have been up- or down-regulated to develop transgenic lines with altered antioxidants levels. Over-expression of enzymes involved in AsA biosynthesis has been shown to confer oxidative stress tolerance in tomato plants (Zhang et al., 2011). Increased AsA content has been also demonstrated to enhance high light stress tolerance in Arabidopsis (Wang et al., 2010). Higher concentration of GSH has proven to protect potato plants against oxidative damage (Eltayeb et al., 2010). Moreover, reduced level of lightmediated cellular damage has been observed in transgenic tobacco plants over-expressing chloroplast-localized $\mathrm{Cu} /$ Zn-SOD (Gupta et al., 1993) and thylakoid membranebound APX (Yabuta et al., 2002). MDHAR over-expression in Arabidopsis has been demonstrated to enhance the tolerance towards photo-oxidative stresses (Li et al., 2010). Moreover, some studies have reported that combined expression of antioxidant enzymes in transgenic plants acts synergistically on stress tolerance, e.g. simultaneous over-expression of $\mathrm{Cu} / \mathrm{Zn}-\mathrm{SOD}$ and APX in tobacco chloroplasts enhances the resistance to the photo-oxidative stress in comparison to their single over-expression (Tang et al., 2006).

\section{UV Radiation Stress}

Being exposed to sunlight, plants need to deal with the damaging effect of ultraviolet (UV) radiation which reduces the genome stability, impeding their growth and productivity. These effects result from damage to cell components including not only nucleic acids, but also proteins and membrane lipids. Upon UV exposure, strongly mutagenic cross-linked forms of DNA can be produced (Britt, 1999). In order to minimize effects of UV radiation, plants accumulate UV-absorbing secondary metabolites, perform the monomerization of UV-induced pyrimidine dimers (DNA repair) and neutralize generated ROS (Molinier et al., 2005, Kunz et al., 2006). UV radiation consists of UV-C (below $280 \mathrm{~nm}$ ), UV-B (280-320 nm) and UV-A (320-390). Although UV-C is not physiologically relevant to plants since it is efficiently blocked by the stratosphere, the UV-C-triggered cell damage is comparable to induced with UV-B radiation, which reaches Earth's surface (Danon and Gallosis, 1998). Therefore, UV-C radiation has been widely 
used to study DNA damage and repair mechanisms upon UV stress (Sinha et al., 2002). UV has been demonstrated to trigger apoptosis in animals (Babu et al., 2003) and apoptosislike changes in Arabidopsis, including DNA laddering, changes in nucleus morphology (crescent shape) and its fragmentation (Danon and Gallosis, 1998). It has been also proven to induce oxidative burst in plant cells (Babu et al., 2003), considered as the main cause of cell death, which aims at the limitation of damage spreading. Light is necessary for UV-C-triggered cell death and caspase-like proteases participating in this process since caspase-inhibitors are able to block the onset of DNA fragmentation (Essemine et al., 2010, Zhang et al., 2009). Recent study performed on Arabidopsis protoplasts has shown that during the early stage of UV stress, a burst of ROS in chloroplasts and adjacent mitochondria is detected. Mitochondria dysfunction has been also observed, manifested by changes in their distribution, mobility and the loss in mitochondrial trans-membrane potential. Moreover, the pre-incubation with antioxidant molecule - ascorbic acid or inhibitor of photosynthetic electron transport - DCMU decreases the ROS production and retards PCD. These results prove that mitochondria and ROS act as mediators in the UV-C-induced cell death (Gao et al., 2008) and that AsA can be considered as an important antioxidant during this process (Gao and Zhang, 2008), which is consistent with what has been reported in various types of PCD. It has been also shown that Arabidopsis proteins AtDAD1 and AtDAD2 (defender against apoptotic death), localized in the endoplasmic reticulum membrane can suppress DNA fragmentation, indicating an involvement of the ER in UV-Ctriggered PCD pathway (Essemine et al., 2010). The microarray approach has identified numerous genes responsible for ROS scavenging, signalling, transcription regulation and involved in DNA replication or conformation changes that have been deregulated after exposure to UV-C radiation (Molinier et al., 2005). Metacaspase-8 (AtMC8) has been proven to be strongly up-regulated by UV-C. Over-expression of AtMC8 in Arabidopsis has resulted in more severe cell death, while knocking-out AtMC8 has reduced the UV-C-triggered PCD, which suggests that metacaspase- 8 is a part of PCD pathway activated by UV radiation (He et al., 2008). The activation of PCD program upon UV helps plants in eliminating damaged cells to control cell quality and quantity after the trauma.

\section{Drought Stress-soil Water Deficit}

Drought is one of the most unfavorable environmental factors that affects growth and development of plants and consequently limits plant productivity. Plants have developed specific acclimation and adaptation mechanisms to survive the soil water deficit. In response to drought, plants can exhibit either escape (ability to complete the life cycle before severe stress) or resistance mechanisms. Resistance mechanisms include drought avoidance and drought tolerance. The latter depends on the cell turgor maintenance by accumulating osmolytes and soluble sugars (Harb et al., 2010). There are several examples of molecules that help to maintain an osmotic balance under dehydration conditions: sugars, polyols and proline (Yoshiba et al., 1997). Proline is accumulated in the cytoplasm and chloroplast stroma while other solutes (sugars, organic acids, potassium) are cumulated in the vacuole. When the cellular water content decreases, they stabilize cellular structures through hydrophilic interactions and hydrogen bonding (Verslues and Sharma, 2010).

In figure 1 it shows unique physiological characteristics of drought and heat stress combination. A combination of drought and heat stress is shown to be different from drought or heat stress by having a unique combination of physiological parameters.

Photosynthesis is one of major processes affected by water deficit since stomata closure causes reduced $\mathrm{CO}_{2}$ diffusion to the chloroplast. As a result of the inhibition of photosynthesis and the predominance of photorespiration, ROS are generated (Noctor et al., 2002). It has been demonstrated that in drought-stressed plants, the ABA-controlled stomata closure is mediated by $\mathrm{H}_{2} \mathrm{O}_{2}$ (Pei et al., 2000). Under severe drought stress, some antioxidant enzymes have been shown to be highly induced (Dat et al., 2000). However, studies on many drought-stressed crop species showed an inconsistency in their expression since in some cases they have been induced, but in other repressed, suggesting that different ROS balance may be required during different response phases (Cruz and Carvalha, 2008). Recent studies have shown that the water deficit triggers PCD not only in green tissues but also in plant root tips. Apical meristem cells of primary roots undergoing $P C D$, demonstrate increased size of vacuole, degradation of organelles and the collapse of plasma membrane (Duan et al., 2010).

\subsection{ROS - reactive oxygen species}

During water deficit, ROS are responsible for the induction of leaf senescence, which is executed through the programmed cell death and plays an important role in the plant survival (Petrov et al., 2015). This is an active, genetically controlled process which is initiated to isolate and remove damaged tissues thereby ensuring the survival of the organism. It contributes to the nutrients remobilisation during stress and allows the rest of plant to benefit from them and stay alive. Plants can perceive biotic and abiotic stresses via specific receptors. The stress recognition is usually followed by production of messengers such as reactive oxygen species (ROS) or Inositol-1, 4, 5-triphosphate (IP3), and modulatation of intracellular calcium $\left(\mathrm{Ca}^{2+)}\right.$. Production of these early messengers can be receptor mediated, however, in many abiotic stresses (e.g. drought, cold, salt stress) membrane over-excitation can directly lead to ROS generation. The messengers also seem to influence each other, e.g., via IP3 gated calcium channels. Receptors, ROS or $\mathrm{Ca}^{2+}$ dependent signals initiate specific phosphorylation cascades (e.g. mitogen 
activated protein kinases - MAPK, calcium dependent protein kinases - CDPK) and finally interact with the promotor regions of transcription factors (TF) and response genes. The regulation of gene transcription can additionally depend on the activity of plants hormones and other regulatory molecules (e.g. Abscidic acid - ABA, salicylic acid - SA, Jasmonic acid - JA, ethylene - ET). The plant hormones can also influence the ROS and $\mathrm{Ca}^{2+}$ levels and initiate a second round of signaling.

\section{Wind Stress}

It is commonly thought that wind must play a part in the formation of this peculiar forest; to date there is no consensus about how wind influences elfin forest stature. Some authors have viewed elfin stature as the result of severe mechanical stress (Beard, 1949; Howard, 1968). Others have suggested that elf-in stature can be attributed to wind-induced water or nutrient stress (Schimper, 1903; Shreve, 1914; Seifriz, 1953; Odum, 1970; Weaver et al., 1973; Leigh, 1975). The common feature of all these explanaions is that they rest upon the assumption that elfin stature is a pathological condition.

Plants generally respond to environmental stress by adjusting their growth to reduce that stress (Levitt, 1972; Evans, 1972). For instance, Jacobs (1954) attached guy wires to young Pinus radiata $\mathrm{D}$. Don on an Australian plantation to prevent their swaying in the wind. He then compared their growth to that of unguyed trees. The unguyed trees grew less in height and more in trunk diameter than the trees with the mechanical support of the guy wires.

Thigmomorpho-genetic response to mechanical stress, especially wind stress, has been observed in a wide variety of vascular plants (Jacobs, 1954; Whitehead, 1962; Larson, 1963; Neel and Harris, 1971; Jaffe, 1973, 1976, 1980; Grace and Russell, 1977; Ashby et al., 1979). In trees the most conspicuous thigmomorpho-genetic response is retarded stem elongation and increased radial growth (Jacobs, 1954; Larson, 1963, 1965; Neel and Harris, 1971; Ashby et al., 1979).

Grubb and Tanner (1976) and Grubb (1977) have suggested that wind-clipping is rare in tropical mountains, and that wind therefore has little influence upon the regulation of forest stature. However, growth responses such as those observed in $D$. pittieri might have major effects upon forest stature in windy locales. In general, ridges are windier than adjacent valleys and slopes (Geiger, 1961; Grace, 1977). Persistent strong winds are a commonly noted feature of the elfin forest environment (Shreve, 1914; Brown, 1919; Gleason and Cook, 1927; Seifriz, 1923, 1943, 1953; Beard, 1955; Baynton, 1968; Lawton, 1980). If, in response to the mechanical stresses of wind, stem elongation is retarded, while radial growth continues apace, then trees of similar age should be shorter and have thicker stems on ridges. Presumably, short, thick trunks, branches and twigs would be less susceptible to wind-clipping. Therefore the absence of conspicuous windclipping is not necessarily a good indication that wind plays an unimportant role in the regulation of forest stature.

\section{Conclusion}

Abiotic stresses will remain a challenge to the natural environment and agriculture. The early evolution of land plants took place under dry conditions with extremes of temperature and harsh sunlight, while crop domestication occurred later in more favorable environments. Subsequently, the selection of plants for productivity traits did not always result in crops that are productive under random stress factors, although the natural variations of crops are genetic reservoirs for abiotic stress adaptation.

\section{References}

Ahamed, K.U., Nahar, K., Fujita, M., Hasanuzzaman, M., 2010. Variation in plant growth, tiller dynamics and yield components of wheat (Triticum aestivum L.) due to high temperature stress. Advances in Agriculture \& Botanics 2, 213-224.

Al-busaidi, A., Ahmed, M., Chikara, J., 2012. The impact of heat and water stress conditions on the growth of the biofuel plant Jatropha curcas. International Journal of Environmental Studies 69, 273-288.

Angadi, S.V., Cutforth, H.W.M., McConkey, B.G., 2000. Seeding management to reduce temperature stress in Brassica species. Saskatchewan Soils and Crops Proceedings. http://www.usask.ca/soilsncrops/conferenceproceedings/previous_years/Files/2000/2000docs/435. pdf

Ashby, W.C., Hendricks, T.R., Kolar, C.A., Phares. R.E., 1979. Effects of shaking and shading on growth of three hardwood species. Forest Science 25, 212-216.

Ashraf, M., Hafeez, M., 2004. Thermotolerance of pearl millet and maize at early growth stages: growth and nutrient relations. Biologia Plantarum 48, 81-86.

Babu, T.S., Akhtar, T.A., Lampi, M.A., Tripuranthakam, S., Dixon, D.G., Greenberg, B.M., 2003. Similar stress responses are elicited by copper and ultraviolet radiation in the aquatic plant lemna gibba: Implication of reactive oxygen species as common signals. Plant Cell Physiology 44(12), 1320-1329.

Baynton, H.W., 1968. The ecology of an elfin forest in Puerto Rico. The microclimate of Pico del Oeste. Journal of Arnold Arboretum. Harvard University, 49, 419-430.

Beard, J.S., 1949. The natural vegetation of the wind-ward and leeward Islands. Oxford Forestry Member, Clarendon Press, Oxford, 21.

Beard, J.S., 1955. The classification of tropical American vegetation types. Ecology 36, 89-100.

Boudsocq, M., Lauriere, C., 2004. Osmotic Signaling in Plants: Multiple pathways mediated by emerging kinase families. Plant Physiology 138(3), 1185-1194.

Britt, A., 1999. Molecular genetics of DNA repair in higher plants. Trends in Plant Science 4(1), 20-25. 
Brown, W.H., 1919. Vegetation of Philippine mountains. Department of Agriculture and Natural Resources, Bureau of Science Publication, 13. Manila.

Cheong, Y.H., Chang, H.S., Gupta, R., Wang, X., Zhu, T., Luan, S., 2002. Transcriptional profiling reveals novel interactions between wounding, pathogen, abiotic stress and hormonal responses in Arabidopsis. Plant Physiology 129, 661-677.

Cruz, D., Carvalho, M.H., 2008. Drought stress and reactive oxygen species. Plant Signaling and Behavior 3(3), 156-165.

Danon, A., Gallois, P., 1998. UV-C radiation induces apoptoticlike changes in Arabidopsis thaliana. FEBS Letter 437(1-2), 131-136.

Dat, J., Vandenabeele, S., Vranova, E., Van Montagu, M., Inze, D., Van Breusegem, F., 2000. Dual action of the active oxygen species during plant stress responses. Cellular and Molecular Life Science 57(5), 779-795.

Dellaporta, S.L., Calderon-Urrea, A., 1993. Sex determination in flowering plants. Plant Cell 5(10), 1241-1251.

Duan, Y., Zhang, W., Li, B., Wang, Y., Li, K., Sodmergen, B., 2010. An endoplasmic reticulum response pathway mediates programmed cell death of root tip induced by water stress in Arabidopsis. New Phytology 186(3), 681-695.

Eltayeb, A.E., Yamamoto, S., Habora, M.E.E., Matsukubo, Y., Aono, M., Tsujimoto, H., 2010. Greater protection against oxidative damages imposed by various environmental stresses in transgenic potato with higher level of reduced glutathione. Breeding Science 60(2), 101-109.

Essemine, J., Ammar, S., Bouzid, S., 2010. Impact of heat stress on germination and growth in higher plants: Physiological, biochemical and molecular repercussions and mechanisms of defence. Journal of Biological Sciences 10, 565-572.

Evans, G.C., 1972. The quantitative analysis of plant growth. University of California Press, Berkeley.

Fukuda, H., 2000. Programmed cell death of tracheary elements as a paradigm in plants. Plant Molecular Biology 44(3), 245-253.

Gan, S. and Amasino, R.M. (1995) Inhibition of leaf senescence by autoregulated production of cytokinin. Science 270 , 1986-1988

Gao, C., Xing, D., Li, L., Zhang, L., 2008. Implication of reactive oxygen species and mitochondrial dysfunction in the early stages of plant programmed cell death induced by ultraviolet-C overexposure. Planta 227(4), 755-767.

Gao, Q., Zhang, L., 2008. Ultraviolet-B-induced oxidative stress and antioxidant defense system responses in ascorbatedeficient vtc1 mutants of Arabidopsis thaliana. Journal of Plant Physiology 165(2), 138-1348.

Geiger, R., 1961. The climate near the ground. Harvard University Press, Cambridge.

Gleason, H.A., Cook, M.T., 1927. Plant ecology of Porto Rico and Science Survey. Porto Rico Virgin Is 7, 1-173.

Grace, J., Russell, G., 1977. The effect of wind on grasses. Influence of continuous drought or wind on anatomy and water relations. Journal of Experimental Botany 28, 268-278.

Grace, J., 1977. Plant response to wind. Academic Press, New York.

Gray, J., Janick-Buckner, D., Buckner, B., Close, P.S., Johal, G.S., 2002. Light-dependent death of maize Ils1 cells is mediated by mature chloroplasts. Plant Physiology 130(4), 1894-1907.

Grubb, P.J., Tanner, E.V., 1976. The montane forests and soils of Jamaica: a reassessment. Journal of Arnold Arboretum. Harvard University, 57, 313-368.

Grubb, P.J., 1977. Control of forest growth and distri- bution on wet tropical mountains, with special ref- erence to mineral nutrition. Annual Review of Ecology and Systematic 8, 83-107.

Gunawardena, A., 2008. Programmed cell death and tissue remodelling in plants. Journal of Experimental Botany 59(3), 445-451.

Gunawardena, A., Greenwood, J.S., Dengler, N.G., 2004. Programmed cell death remodels lace plant leaf shape during development. Plant Cell 16(1), 60-73.

Gupta, A.S., Heinen, J.L., Holaday, A.S., Burke, J.J., Allen R.D., 1993. Increased resistance to oxidative stress in transgenic plants that overexpress chloroplastic $\mathrm{Cu} /$ Zn superoxide dismutase. Proceeding of the National Academy of Science, U.S.A., 90(4), 1629-1633. https:// www.ncbi.nlm.nih.gov/pmc/articles/PMC45928/

Harb, A., Krishnan, A., Ambavaram, M.M.R., 2010. Pereira a molecular and physiological analysis of drought stress in Arabidopsis reveals early responses leading to acclimation in plant growth. Plant Physiology 154(3), 1254-1271.

Hasanuzzaman, M., Hossain, M.A., 2012. Plant Responses and tolerance to abiotic oxidative stress: antioxidant defenses is a key factors. In: Bandi, V., Shanker, A.K., Shanker, C., Mandapaka, M. (Eds.), Crop stress and its management: Perspectives and strategies. Berlin: Springer, 261-316.

He, R., Drury, G.E., Rotari, V.I., Gordon, A., Willer, M., Farzaneh, T., 2008. Metacaspase-8 modulates programmed cell death induced by ultraviolet light and $\mathrm{H}_{2} \mathrm{O}_{2}$ in Arabidopsis. Journal of Biological Chemistry 283(2), 774-783.

Howard, R.A., 1968. The ecology of an elfin forest in Puerto Rico. Introduction and composition studies. Journal of Arnold Arboretum. Harvard University, 49, 381-418.

Jabs, T., Dietrich, R.A., Dangl, J.L., 1996. Initiation of Runaway Cell Death in an Arabidopsis mutant by extracellular superoxide. Science 273(5283), 1853-1856.

Jacobs, M.R., 1954. The effect of wind sway on the form and development of Pinus radiata. Australian Journal of 
Botany 2, 35-51.

Jaffe, M.J., 1973. Thigmomorphogenesis: the response of plant growth and development to mechanical stress, with special reference to Bryonia dioica. Planta 114, 143-157.

Jaffe, M.J., 1976. Thigmomorphogenesis: a detailed characterization of the response of beans (Phaseolus vulgaris L.) to mechanical stimulation. Z. Pflanzenphysiology 77, 437-453.

Jaffe, M.J., 1980. Morphogenetic responses of plants to mechanical stimuli or stress. Bioscience 30, 239-243.

Jiang, Q.W., Kiyoharu, O., Ryozo, I., 2002. Two novel mitogenactivated protein signalling components, OsMEK1 and OsMAP1, are involved in a moderate low-temperature signaling pathway in Rice. Plant Physiology 129, 1880-1891.

Johkan, M., Oda, M., Maruo, T., Shinohara, Y., 2011. Crop production and global warming. In: Casalegno, S. (Ed.), Global warming impacts- Case studies on the economy, human health, and on urban and natural environments, Rijeka, In Tech, 139-152.

Jump, P., Jiwan, P., Farag, K., 2006. Methods for enhancing plant health, protecting plants from biotic and abiotic stress related injuries and enhancing the recovery of plants injured as a result of such stresses. United States Patent 7101828.

Kunz, B.A., Cahill, D.M., Mohr, P.G., Osmond, M.J., Vonarx, E.J., 2006. Plant responses to UV radiation and links to pathogen resistance. A survey of cell biology. Academic Press, 1-40.

Larson, P.R., 1963. Stem form development of forest trees. For. Sci. Monogr., 5, 1-42. http://www.ingentaconnect. com/contentone/saf/fs/1963/00000009/A00504s5/ art00001?crawler=true

Lawton, R.O., 1980. Wind and the ontogeny of elfin stature in a Costa Rican lower montane rain forest. Ph.D. thesis, University of Chicago, Chicago.

Leight, E.G., 1975. Structure and climate in tropical rain forest. Annual Review of Ecology and Systematics 6, 67-86.

Levitt, J., 1972. Responses of plants to environmental stresses. Academic Press, New York.

Li, F., Wu, Q.Y., Sun, Y.L., Wang, L.Y., Yang, X.H. and Meng, Q.W., 2010. Overexpression of chloroplastic monodehydroascorbate reductase enhanced tolerance to temperature and methyl viologen-mediated oxidative stresses. Physiologia Planterum 139(4), 421-434.

Mach, J.M., Castillo, A.R., Hoogstraten, R., Greenberg, J.T., 2001. The Arabidopsis-accelerated cell death gene ACD2 encodes red chlorophyll catabolite reductase and suppresses the spread of disease symptoms. PNAS 98(2), 771-776.

Molinier, J., Oakeley, E.J., Niederhauser, O., Kovalchuk, I., Hohn, B., 2005. Dynamic response of plant genome to ultraviolet radiation and other genotoxic stresses. Mutant Research 571(1-2), 235-247.
Nahar, K., Biswas, J.K., Shamsuzzaman, A.M.M., Hasanuzzaman, M., Barman, H.N., 2009. Screening of indica rice (Oryza sativa L.) genotypes against low temperature stress. Botany Research International 2, 295-303.

Neel, P.L., Harris, R.W., 1971. Motion induced inhibition of elongation and induction of dormancy in Liquidambar. Science 173, 58-60.

Noctor, G., Veljovic-Jovanovic, S., Driscoll, S., Novitskaya, L., Foyer, C.H., 2002. Drought and oxidative load in the leaves of $\mathrm{C}_{3}$ plants: a Predominant role for photorespiration? Annals of Botany 89(7), 841-850.

Odum, H.T., 1970. Rain forest structure and mineral cycling homeostasis. In: Odum, H.T. (Ed.), A tropical rain forest, 3-52. U.S. AEC Div. Tech. Inf., Washington, D.C.

Pei, Z.M., Murata, Y., Benning, G., Thomine, S., Klüsener, B., Allen, G.J., 2000. Calcium channels activated by hydrogen peroxide mediate abscisic acid signalling in guard cells. Nature 406(6797), 731-734.

Pennell, R.I., Lamb, C., 1997. Programmed cell death in plants. Plant Cell 9(7), 1157-1168.

Petrov, V,; Hille, J., Mueller-Roeber, B. and Gechev, S.T. (2015). ROS-mediated abiotic stress-induced programmed cell death in plants. Frontiers of Plant Sciences 6 (69): 1-16.

Porter, J.R., Gawith, M., 1999. Temperature and the growth and development of wheat: A review. European Journal of Agronomy 10, 23-36.

Prasad, P.V.V., Boote, K.J., Allen, Jr. L.H., 2006. Adverse high temperature effects on pollen viability, seed-set, seed yield and harvest index of grain-sorghum [Sorghum bicolor (L.) 9. Moench] extreme temperature responses, oxidative stress and antioxidant defense in plants 191 are more severe at elevated carbon dioxide due to higher tissue temperatures. Agricultural and Forest Meteorology 139, 237-251.

Prasad, P.V.V., Pisipati, S.R., Momcilovic, I., Ristic, Z., 2011. Independent and combined effects of high temperature and drought stress during grain filling on plant yield and chloroplast EF-Tu Expression in spring wheat. Journal of Agronomy Crop Science 197, 430-441.

Prasad, P.V.V., Staggenborg, S.A., Ristic, Z., 2008. Impacts of drought and/or heat stress on physiological, developmental, growth, and yield processes of crop plants. In: Ahuja, L.H. and Saseendran, S.A. (eds) Response of crops to limited water: Understanding and modeling water stress effects on plant growth processes. Advances in Agricultural Systems Modeling Series 1. ASA-CSSA, Madison, Wisconsin: 301-355.

Rahman, M.M., 2004. Response of wheat genotypes to late seeding heat stress. M.Sc. Thesis. Department of Crop Botany. Bangabandhu Sheikh Mujibur Rahman Agricultural University, Gazipur, Bangladesh.

Roberts, M.R., Salinas, J., Collinge, D.B., 2002. 14-3-3 proteins and the response to abiotic and biotic stress. Plant Molecular Biology 50, 1031-1039. 
Schimper, A.F.W., 1903. Plant geography upon a phys-iological basis. Oxford University Press, Oxford.

Seifriz, W., 1923. The altitudinal distribution of plants on Mt. Gedeh, Java. Bull. Torrey Botanical Club 50, 283-305.

Seifriz, W., 1943. The plant life of Cuba. Ecological Monographs 13, 375-426.

Seifriz, W., 1953. The altitudinal distribution of plants on Mt. Gedeh, Java. Bull. The ecology of thicket formation. Veg-etatio 4, 155-164.

Shah, F., Huang, J., Cui, K., Nie, L., Shah, T., Chen, C., Wang, K., 2011. Impact of high temperature stress on rice plant and its traits related to tolerance. Journal of Agricultural Science149, 545-556.

Shreve, F., 1914. A montane rain-forest. A contribution to the physiological plant geography of Jamaica. Car-negie Inst. of Washington, Publ. No. 109.

Sinha, R.P., Hader, D.P., 2002. UV-induced DNA damage and repair: a review. Photochemical and Photobiological Sciences 1(4), 225-236.

Solanke, A.U., Sharma, A.K., 2008. Signal transduction during cold stress in plants. Physiology and Molecular Biology of Plants 14, 69-79.

Tang, L., Kwon, S.Y., Kim, S.H., Kim, J.S., Choi, J.S., Cho, K.Y., 2006. Enhanced tolerance of transgenic potato plants expressing both superoxide dismutase and ascorbate peroxidise in chloroplasts against oxidative stress and high temperature. Plant Cell Reports 25(12), 1380-1386.

Teppmann, H.F., Schluter, U., Colling, D.B., 2006. Common Themes in biotic and abiotic stress signaling in plants. Global Science book, 52-67.

Vahdati, K., Leslie, C., 2013. Abiotic Stress - Plant Responses and Applications in Agriculture. Published by InTech. Janeza Tradine 9,51000 Rijeka, Croatia.

Verslues, P.E., Sharma, S., 2010. Proline Metabolism and Its Implications for Plant-Environment Interaction. Arabidopsis Book. Published By: The American Society of Plant Biologists, http://www.bioone.org/doi/ full/10.1199/tab.0140
Wahid, A., 2007. Physiological implications of metabolites biosynthesis in net assimilation and heat stress tolerance of sugarcane (Saccharum officinarum) sprouts. Journal of Plant Research 120, 219-228.

Wang, Z., Xiao, Y., Chen, W., Tang, K., Zhang, L., 2010. Increased vitamin C content accompanied by an enhanced recycling pathway confers oxidative stress tolerance in Arabidopsis. Journal of Integrative Plant Biology 52(4), 400-409.

Watanabe, T., Kume, T., 2009. A general adaptation strategy for climate change impacts on paddy cultivation: special reference to the Japanese context. Paddy Water Environment 7, 313-320.

Weaver, P.L., Bruck, D.L., Byer, M.D., 1973. Transpiration rates in the luquillo mountains of Puerto Rico. Biotropica 5, 123-133.

Whitehead, F.H., 1962. Experimental studies of the effect of wind on plant growth and anatomy, Helianthus annuus. New Phytology 67, 59-62.

Yabuta Y., Motoki, T., Yoshimura, K., Takeda, T., Ishikawa, T., Shigeoka, S., 2002. Thylakoidmembrane-bound ascorbate peroxidase is a limiting factor of antioxidative systems under photo-oxidative stress. The Plant Journal 32(6), 915-925.

Yoshiba, Y., Kiyosue, T., Nakashima, K., Yamaguchi-Shinozaki, K., Shinozaki, K., 1997. Regulation of levels of proline as an osmolyte in plants under water stress. Plant Cell Physiology 38(10), 1095-1102.

Zhang, C., Liu, J., Zhang, Y., Cai, X., Gong, P., Zhang, J., 2011. Over expression of SIGMEs leads to ascorbate accumulation with enhanced oxidative stress, cold, and salt tolerance in tomato. Plant Cell Reports 30(3), 389-398.

Zhang, L., Xu, Q., Xing, D., Gao, C., Xiong, H., 2009. Real-time detection of caspase-3-like protease activation in vivo using fluorescence resonance energy transfer during plant programmed cell death induced by ultraviolet C overexposure. Plant Physiology 150(4), 1773-1783. 